\title{
Extended Red Blood Cell Genotyping to Investigate Immunohematology Problems
}

Kyung-Hwa Shin, M.D. ${ }^{1}$, Hyun-Ji Lee, M.D. ${ }^{2}$, Kyung-Hee Park, M.D. ${ }^{3}$, Bae Mi Hye, M.D. ${ }^{3}$, Chulhun L. Chang, M.D. ${ }^{2}$, and Hyung-Hoi Kim, M.D. ${ }^{1}$

Department of Laboratory Medicine and Biomedical Research Institute ${ }^{1}$, Pusan National University Hospital, Busan; Department of Laboratory Medicine ${ }^{2}$, Pusan National University Yangsan Hospital, Yangsan; Department of Pediatrics ${ }^{3}$, Pusan National University Hospital, Busan, Korea

\section{Dear Editor,}

Red blood cell (RBC) genotyping is recommended to limit alloimmunization in patients with sickle cell disease or thalassemia [1]. RBC genotyping can resolve the serologic weak D phenotype and inconclusive RhD typing in obstetrics and identify the RBC phenotype in patients with autoantibodies or a positive direct antiglobulin test (DAT) [2]. DNA-based RBC typing has better accuracy and provides more information on RBC antigens than typical phenotyping [1].

We report a challenging case of a pregnant patient in whom a lack of compatible RBCs, based on RBC genotyping, suggested the presence of anti-Dib and anti-E specificities. To our knowledge, extended RBC genotyping was used to obtain compatible $\mathrm{RBC}$ units for the first time in Korea.

A 36-year-old Korean woman (gravida 2, para 0) came to Pusan National University Hospital for prenatal care. She had a history of blood transfusion at the age of 12 years. Her blood type was B and RhD positive, and she tested positive for irregular antibodies at 30 weeks of gestation. All panels, except for auto-control, were reactive in RBC antibody screening. However, we could not determine the types of the unexpected antibodies; moreover, detection of compatible RBCs was difficult due to the presence of unexpected antibodies. We obtained one unit of compatible packed RBCs (matched for Rh, Kell, Duffy, and Kidd) for practicable 350-unit cross matching and one unit of whole blood from autologous blood donation. The study protocol was approved by the institutional review board of Pusan National University Hospital, and written informed consent was obtained from the patient. Extended genotyping of $37 \mathrm{RBC}$ antigens with the ID CORE ${ }^{X T}$ kit (Progenika Biopharma-Grifols, Bizkaia, Spain) that is based on Luminex XMAP technology predicted the rare blood type Di(a+b-) (Table 1). We hypothesized that the lack of a compatible blood product was due to the presence of anti-Di ${ }^{b}$ antibodies. The patient delivered a female infant by elective cesarean section at 36 weeks of gestation. She received an intra-operative transfusion of autologous whole blood (one unit) and compatible packed RBCs (one unit) one day post-surgery. The Central Laboratory of the Swiss Red Cross in Bern, Switzerland, confirmed the presence of anti-Dib and anti-E antibodies in the patient's serum after delivery. The patient and her infant were discharged from the hospital on day 5 after the cesarean section.

The infant had a birth weight of 2,590 g. Her day 14 laboratory findings were as follows: hemoglobin, $9.74 \mathrm{mmol} / \mathrm{L}$; hematocrit, 0.46 fraction; reticulocyte count, 0.01 fraction; total bilirubin, 107.24 $\mu \mathrm{moL} / \mathrm{L}$; direct bilirubin, $18.81 \mu \mathrm{moL} / \mathrm{L}$; blood group $\mathrm{O}, \mathrm{RhD}$ positive. DAT was positive (1+) for polyspecific anti-hu-
Received: July 22, 2017

Revision received: October 8, 2017

Accepted: January 15, 2018

\section{Corresponding author: Hyung-Hoi Kim}

Biomedical Research Institute, Pusan National University Hospital Clinical Trial Center (CTC), Department of Laboratory Medicine and Biomedical Informatics Unit of Pusan National University School of Medicine,

179 Gudeok-ro, Seo-gu, Busan 49241, Korea

Tel: +82-51-240-7418, Fax: +82-51-247-6560, E-mail: hhkim@pusan.ac.kr

\section{(c) Korean Society for Laboratory Medicine}

This is an Open Access article distributed under the terms of the Creative Commons Attribution Non-Commercial License (http://creativecommons.org/licenses/by-nc/4.0) which permits unrestricted non-commercial use, distribution, and reproduction in any medium, provided the original work is properly cited. 
Table 1. Genotyping and phenotyping of red blood cells in the patient

\begin{tabular}{|c|c|c|c|}
\hline $\begin{array}{l}\text { Blood group } \\
\text { system }\end{array}$ & Genotype & Predicted phenotype & Phenotype \\
\hline $\mathrm{Rh}$ & $\mathrm{RHCE}^{\star} \mathrm{Ce}$ & $\mathrm{Ce}, \mathrm{C}^{\mathrm{w}}-, \mathrm{V}-, \mathrm{hr} \mathrm{S}_{+}, \mathrm{VS}-, \mathrm{hr}^{\mathrm{B}}+$ & DCe \\
\hline Kell & $K E L * k \_K P B \_J S B$ & $K-k+, K p(a-b+), J s(a-b+)$ & $k-k+$ \\
\hline Kidd & $J K^{*} A, J K^{*} B$ & $J k(a+b+)$ & $J k(a+b+)$ \\
\hline Duffy & $\mathrm{FY} * \mathrm{~A}$ & Fy(a+b-) & Fy $(a+b-)$ \\
\hline \multirow[t]{2}{*}{ MNS } & $\mathrm{GYPA}^{*} \mathrm{M}, \mathrm{GYPA}{ }^{*} \mathrm{~N}$ & $\mathrm{M}+\mathrm{N}+$ & $\mathrm{M}+\mathrm{N}+$ \\
\hline & GYPB* $^{*}$ & $\mathrm{~S}-\mathrm{S}+, \mathrm{U}+, \mathrm{Mi}(\mathrm{a}-)$ & S-S+ \\
\hline Diego & $\mathrm{DI}{ }^{*} \mathrm{~A}$ & Di $(a+b-)$ & \\
\hline Dombrock & $\mathrm{D} 0 * \mathrm{~B}$ & $\mathrm{D} 0(\mathrm{a}-\mathrm{b}+), \mathrm{Hy}+, \mathrm{J} 0(\mathrm{a}+)$ & \\
\hline Colton & $C O * A$ & $\mathrm{Co}(\mathrm{a}+\mathrm{b}-)$ & \\
\hline Cartwright & $Y T^{*} \mathrm{~A}$ & $Y t(a+b-)$ & \\
\hline Lutheran & $L U * B$ & $\operatorname{Lu}(a-b+)$ & \\
\hline
\end{tabular}

man IgG. Although the neonate's serum tested negative for unexpected antibodies, the eluate prepared from her RBCs tested positive in the unexpected antibody screening. We suspected the presence of anti-Di ${ }^{b}$ antibodies because all panels, except the auto-control, were reactive in antibody screening. Blood group typing of the infant was not performed as the sample volume was too low.

$\mathrm{Di}^{\mathrm{b}}$ is a high-frequency antigen (HFA) in most populations. Anti$\mathrm{Di}^{\mathrm{b}}$ can cause hemolytic transfusion reactions and serious hemolytic disease in fetuses and newborns [3]. In a report from Korea, the prevalence of the predictive phenotype Di(a+b-) was $0.7 \%$ (3/419) in healthy Korean donors [4]. Anti-Dib was observed in four cases of hemolytic disease in newborns [5-8] and two adult cases in which no matched blood products could be found for orthopedic surgery [9]. In another report, Anti-Di ${ }^{b}$ were detected through a reaction with blood cells for the identification of an unexpected antibody with the Di(a+b-) phenotype; the genotype of the Diego blood type could not be identified [7]. In another case, $\mathrm{Di}^{\mathrm{b}}$ was detected through genotyping of the Diego blood type by direct sequencing of SLC4A1, which encodes the erythroid band 3 protein anion exchanger 1 (AE1) glycoprotein. A mutation resulting in a single amino acid change in this protein resulted in the production of the Diego antigen [3, 9].

Hospitals typically perform time-consuming serologic tests on site to locate antigen-negative RBC units [10]. Antibodies against HFA may be difficult to identify due to a lack of negative panel cells; thus, identifying compatible antigen-negative blood can be challenging. In this case, reactions with all panel cells were positive (except for the auto-control). As it is difficult to identify anti- bodies in the hospital, samples are typically sent to a reference blood bank or laboratory for antibody identification through additional tests; however, this process is time-consuming. In this case, we could predict anti-Dib antibodies through extended RBC genotyping because we suspected antibodies against HFAs. RBC genotyping can be performed immediately at the hospital. In conclusion, in cases in which antibody identification and detection of compatible RBCs are difficult, antibodies against HFAs can be suspected. Extended RBC genotyping is a useful tool to identify specific anti-HFA antibodies and identify compatible RBCs for patients with these antibodies in transfusion medicine laboratories at hospitals.

\section{Authors' Disclosures of Potential Conflicts of Interest}

No potential conflicts of interest relevant to this article were reported.

\section{REFERENCES}

1. Casas J, Friedman DF, Jackson T, Vege S, Westhoff CM, Chou ST. Changing practice: red blood cell typing by molecular methods for patients with sickle cell disease. Transfusion 2015;55:1388-93.

2. Keller MK. The role of red cell genotyping in transfusion medicine. Immunohaematology 2015;31:49-52.

3. Fung MK, Hillyer CD, Grossman BJ, Westhoff CM. Technical Manual 18th ed. Bethesda, MD: AABB Press, 2014.

4. Hong YJ, Chung Y, Hwang SM, Park JS, Kwon JR, Choi YS, et al. Genotyping of 22 blood group antigen polymorphisms and establishing a national recipient registry in the Korean population. Ann Hematol 2016; 95:985-91

5. Park MH, Son J, Go JW, Kim JY, Ahn DH, Kim DA. A case of hemolytic disease of the newborn due to anti-Dib Antibody. J Korean Soc Neonatol 1999;6:268-7.

6. Choi JW, Kim MJ, Kim MH, Park JR, Kim HO. A case of mild hemolytic disease of the fetus and newborn - The first case of anti-Dib identified on prescreening test during pregnancy. Korean J Blood Transfus 2010; 21:165-70.

7. Kim HC, Kang MJ, Chae JH, Shim WS, Nahm CH, Hah KS. A case of hemolytic disease of the newborn due to anti-Dib antibody. Korean $J$ Blood Transfus 1994;5:151-8.

8. Oh EJ, Jekarl DW, Jang HS, Park HI, Park YJ, Choi HA, et al. Severe hemolytic disease of the newborn due to anti-Dib treated with phototherapy and intravenous immunoglobulin. Ann Clin Lab Sci 2008;38: 80-2.

9. Lee MY, Park TS, Oh SH, Kim SY, Kim HO. Two clinical cases of antiDib with Di(a+b-) phenotypes: practical need for rare blood donor registry program in Korea. Lab Med Online 2017;7:79-82.

10. Flegel WA, Gottschall JL, Denomme GA. Integration of red cell genotyping into the blood supply chain: a population-based study. Lancet Haematol 2015;2:e282-8. 